Indonesian Journal of Medicine (2016), 1(3): 169-174

https://doi.org/10.26911/theijmed.2016.01.03.04

\title{
The Relationship Between Parenting Style, Development Stimulation, and Gross Motoric and Language Ability in Children Under Five
}

\author{
Dhiyan Nany Wigati'), Didik Tamtomo's,3), Yulia Lanti Retno Dewi²,3) \\ 1)An-Nur Midwifery Academy, Purwodadi, Central Java \\ ${ }^{2)}$ Masters Program in Public Health, Sebelas Maret University, Surakarta \\ 3)Faculty of Medicine, Sebelas Maret University, Surakarta
}

\begin{abstract}
Background: Children progress through growth and development process according to age. Child growth and development are influenced by genetic and environmental factors during antenatal, intranatal, and postnatal periods. Child development is optimalized if there is social interaction that fulfill the need of the child at different stages of development. This study investigated the relationship between parenting style, development stimulation, and gross motoric and language ability in children under five in Grobogan, Central Java.

Subjects and Method: This was an analytic observational study with cross sectional design. This study was conducted in Toroh I Health Center, Grobogan sub-district, Central Java, from September, 17 to October, 17 2016. A total sample of 100 mothers and their children aged 1-5 years were selected for this study by cluster sampling. The dependent variable was gross motoric and language ability. The independent variables were parenting style and development stimulation. Gross motoric and language ability was measured by Denver II. Parenting style and development stimulation were collected by a set of questionnaire. The data were analyzed by multiple logistic regression.

Results: There were positive and statistically significant relationships between democratic parenting style $(\mathrm{OR}=3.73 ; 95 \% \mathrm{CI}=1.16$ to $12.00 ; \mathrm{p}=0.027)$, development stimulation $(\mathrm{OR}=5.37$; $95 \% \mathrm{CI}=1.75$ to $16.47 ; \mathrm{p}=0.003$ ), and better gross motoric ability. There were positive and statistically significant relationships between democratic parenting style $(\mathrm{OR}=3.50 ; 95 \% \mathrm{CI}=1.18$ to $10.35 ; \mathrm{p}=0.023)$, development stimulation $(\mathrm{OR}=3.49 ; 95 \% \mathrm{CI}=1.24$ to $9.84 ; \mathrm{p}=0.018)$, and better language ability.
\end{abstract}

Conclusion: Democratic parenting style and development stimulation are associated with both better gross motoric ability and better language ability.

Keywords: parenting style, development stimulation, gross motoric ability, language ability

\section{Correspondence:}

Dhiyan Nany Wigati. An-Nur Midwifery Academy, Purwodadi, Central Java.

Email: dhiyanwigati@gmail.com.

\section{BACKGROUND}

Parent, caregiver, and educator should fulfill children's basic needs for them to optimally grow also carry out quality and comprehensive guidance as well as set the foundation for physical and mental health, logic and reasoning ability, personality development, adjusting ability with social cultural environment. The first priority of children guidance is to meet their basic needs (nurture, love, and teach/ early agestimulation to boost body and brain development since early age), discover and interfere since early age to mend growth deviation occurred (Soetjiningsih, 2013).

Parenting style is classified into three, namely authoritarian parenting, permissive parenting, and democratic parenting. In authoritarian parenting, parents impose discip- 
line toward their children and demand high achievement. However, in the other sides parents do not give their children the opportunity to convey their opinion, whereas in permissive parenting parents show intense democratic manner and love, but with low control and achievement demand. Moreover in democratic parenting, parents give control by requiring children to achieve certain target. However, parents also give their children the opportunity to convey their complaints and opinions. The right parenting style is varied, it depends on the problems faced by children or the condition of the child him/ herself (Wong et al., 2008).

Every child will go through development process in accordance with their ages and stages, however there are a lot of factors that interfere among others are genetic factor and prenatal, perinatal, and postnatal environment. The other factors that may interfere children development are factor of age, maternal education, family income, number of children, maternal working load, psychosocial parenting style, parental personality, custom, religion, urbanization, political life, and stimulation given by parents (Asiyah et al., 2010; Ariani et al., 2012).

Development monitoring should be conducted since early age in order to recognize children development disruption so that the development of movement, speech and language, socialization and self reliance ability on children optimally occur in accordance with their age (Susanto, 2011). Furthermore, there are factors that influence children development which are internal and external factors. Internal factors include genetic and hormone influence, whereas external factor includes environment. Parent is included in environment factor, which is family environment. Parent conducts interaction for the first time with their children to develop children's ability in accordance with their developmental age.
Stimulation implementation will be effective if it pays attention to children's needs in accordance with their development especially if it is applied during critical period (golden period) that is the first two years of a child life (Soetjiningsih, 2013). One of the children developments which is important to be monitored during this period is motor development since there are a lot of cognitive performances which are rooted from the achievement of motor development. Combination between positive mother and children interaction, physical exercise and early stimulation will improve children's motor development (Christi et al., 2013).

There is a critical period during children development, in which it takes beneficial stimulation for children potential can develop, therefore it needs our awareness. Psychosocial development is extremely affected by environment and interaction among children with parents/ other adults. Children development will be optimal if social interaction is cultivated in accordance with the children's needs in various stages of development, even since baby is still in the womb (Soetjiningsih, 2013).

A child may endure developmental delay in only one area of development, or it may occur in more stages of development. Global development delay is a condition of development delay which is due on two or more stages of development. In general, children's developmental stages consist of gross motor, fine motor, language/speech, and personal social/self reliance. Around 5 up to $10 \%$ children are estimated endure developmental delay. Number of general developmental delay data is not yet accurately identified, however it is estimated around $1-3 \%$ of children under 5 years old endure general development delay (IDAI, 2013).

The result of growth early detection conducted by Health Department of Republic of Indonesia (2009) shows that children de- 
velopmental delay nationwide in 2009 was 29\%. In 2014 the coverage of toddlers' visits was as much as $80.0 \%$ therefore the target of Strategic Plan $85 \%$ was not attained (Kemenkes RI, 2015). The percentage of toddlers service in Central Java in 2015 was 86.2\%, a bit decreasing than toddlers service in 2014 that was $86.9 \%$. Toddlers service is one of the developmental monitoring which includes the assessment of development of gross motor, fine motor, speech and language as well as socialization and self reliance, hearing and sight examination (Dinkes Jateng, 2015).

Number of toddlers in Grobogan Regency in 2015 was 90,534, whereas those who carried out toddlers visit was $80.07 \%$. The percentage was still below national target, that was 90\%. Toddlers visit includes the activity of Stimulation, Detection, and Growth Early Intervention (SDIDTK). It is a comprehensive and quality children growth coaching through stimulation, early detection of growth deviation in the first 5 years. The implementation of SDIDTK in Toroh Sub-district did not yet attain $50 \%$ of the targeted toddlers, which were 4,089 children in 2015 .

\section{SUBJECTS AND METHOD}

The design of the study was observational analysis. The approach used was cross sectional. The study took place in the working area of Toroh I Puskesmas (Community Health Center), Toroh Sub- district, Grobogan Regency. The independent variable was parenting style and development stimulation. Dependent variables were gross motor and language. Multi stage sampling techniques were cluster sampling and purposive sampling. Data collection instruments used were questionnaires and Denver II sheets. Data analysis used was logistic regression.

\section{RESULTS}

Table 1 shows that most of research subjects are from young adult age group (84\%), educated up to secondary school (35\%), and housewives (65\%).

Table 2 shows that in logistic regression analysis it is observed that there is a positive relationship and statistically significant between democratic parenting style and gross motor on toddlers $(\mathrm{OR}=3.73$; $95 \% \mathrm{CI}=$ 1.16 to $12.00 ; \mathrm{p}=0.027)$. Children who are nurtured with democratic parenting style own normal gross motor ability which is 4 times bigger than those who are nurtured with permissive and authoritarian parenting style.

There is a positive relationship and statistically significant between the frequent implementation of development stimulation and gross motor ability $(\mathrm{OR}=5 \cdot 37$; $95 \% \mathrm{CI}=$ 1.75 to $16.47 ; \mathrm{p}=0.003)$. Toddlers who are frequently given development stimulation own normal gross motor ability which is 5 times bigger than those who are seldom given development stimulation. Table 3 shows that in logistic regression analysis it is observed that there is positive relationship and statistically significant between democratic parenting style and language ability on toddlers $(\mathrm{OR}=3.50 ; 95 \% \mathrm{CI}=1.18$ to 10.35 ; $\mathrm{p}=0.023)$. Children who are nurtured with democratic parenting style own normal language ability which is 4 times bigger than those who are nurtured with permissive and authoritarian parenting style.

There is a positive relationship and statistically significant between frequent implementation of development stimulation with language ability $(\mathrm{OR}=3.49 ; 95 \% \mathrm{CI}=$ 1.24 to $9.84 ; \mathrm{p}=0.018)$. Toddlers who are frequently given development stimulation own normal language ability which is 3 times bigger than those who are seldom given development stimulation. 
Table 1. Characteristics of research subjects

\begin{tabular}{ccc}
\hline \multicolumn{1}{c}{ Variables } & n & \% \\
\hline Parents' Age Group & & \\
- Young Adult & 84 & 84 \\
- Adult & 16 & 16 \\
Parents' Education & & \\
- Primary & 22 & 22 \\
- Secondary & 35 & 35 \\
- High School & 31 & 31 \\
- Diploma III & 7 & 7 \\
- University/ Undergraduate & 5 & 5 \\
Pekerjaan & & \\
- Housewives & 65 & 65 \\
- Self Employed & 19 & 19 \\
- Farmers & 14 & 14 \\
- Civil Servants & 2 & 2 \\
\hline
\end{tabular}

Table 2. Relationship between parenting style and development stimulation with gross motor ability

\begin{tabular}{lcccc}
\multicolumn{1}{c}{ Variables } & \multirow{2}{*}{ OR } & \multicolumn{2}{c}{$\mathbf{9 5 \%}$ CI } & p \\
\cline { 3 - 4 } & & Lower Limit & Upper Limit & 0.027 \\
\hline Democratic Parenting Style & 3.73 & 1.16 & 12.00 & 0.003 \\
Frequent development stimulation & $5 \cdot 37$ & 1.75 & 16.47 & 0 \\
N Observation = 100 & & & & \\
\hline
\end{tabular}

Table 3. Relationship between parenting style and development stimulation with language ability

\begin{tabular}{lcccc}
\hline \multirow{2}{*}{ Variables } & \multirow{2}{*}{ OR } & \multicolumn{2}{c}{ 95\% CI } & \multirow{2}{*}{ p } \\
\cline { 3 - 4 } & & Lower Limit & Upper Limit & \\
\hline Democratic Parenting Style & 3.50 & 1.18 & 10.35 & 0.023 \\
Frequent Development & 3.49 & 1.24 & 9.84 & 0.018 \\
Stimulation & & & & \\
N Observation = 100 & & & \\
\hline
\end{tabular}

\section{DISCUSSION \\ 1. Relationship between Parenting Style and Stimulation with Gross Motor Ability on Toddlers in Toroh Sub District Grobogan Regency}

The relationship analysis between independent variables with gross motor ability on toddlers using logistic regression test found that from both variables which is related to gross motor ability was parenting style and development stimulation, the variable with stronger relationship was development stimulation $(\mathrm{OR}=5.37)$ it meant that toddlers who were frequently given development stimulation own normal gross motor ability which is 5 times bigger than those who were seldom given development ability.

Study conducts by Inneke and Purwanti (2014) find that children and parents/ caregivers who more actively and simultaneously conduct stimulation showed better development. Study by Sharma and Nagar in India on children aged 0-18 months shows that babies and kids who are given intervention, such as toys that stimulate children development and promote parental involvement in nurturing children, ensuring home is in safe condition, as well as give parents some understanding toward milestone of children development, their motor examination is better. The success of stimulation does 
not depend on parents' education, however it depends on the effectiveness and continuity of stimulation on children.

Stimulation from environment is the most important thing for the children's growth. Children who are given directed and consistent stimulation will develop faster than children who are lack of/ without stimulation. Stimulation also optimizes genetic potential possessed by children. Conducive environment will promote good physical and mental development. Less supporting environment will result in children develop below their genetic potential (Soetjiningsih, 2013).

\section{Relationship between Parenting} Style and Stimulation with Language Ability on Toddlers in Toroh

\section{Sub District Grobogan Regency}

Cohen et al (2012) studies the influence of interaction between caregivers and children toward children's receptive language development. Out of 50 children being studied, Cohen finds children with better speech development come from groups whose caregivers talk frequently and interact with children in verbal as well as non verbal language in positive manner. In the opposite, children whose caregivers are authoritarian have less speech development. The study in analyzing the relationship between independent variables with language ability on toddlers by using logistic regression test, found that out of both variables related to language ability that were parenting style and development stimulation, it was parenting style that was variable with the strongest relationship $(\mathrm{OR}=3.50)$ it meant that toddlers who get democratic parenting style owned normal language ability which was 4 times bigger that those with permissive and authoritarian parenting style.

Pancsofar and Vemon Feagans study (2006) states that educated family and has good economy status is likely to have children with lower risk of experiencing language and speech development delay. The study shows that children in day care experience good speech and language development with well educated care givers ( parents and care givers in day care) and also come from family with good economy condition. Education level is one of factors of children nurturing quality. Study of National Institute Of Child Health And Human Development (NICHD) concludes that children who obtain high quality nurture consistently show better cognitive function and language development during the first three years of their life.

\section{REFERENCE}

Ariani YM (2012). Usia anak dan pendidikan ibu sebagai faktor risiko gangguan perkembangan anak. Jurnal Kedokteran Brawijaya 27: 118-121.

Asiyah S, Harjito K, Suwoyo (2010). Efektivitas metode stimulasi satu jam bersama ibu terhadap perkembangan anak usia 12-24 bulan. Jurnal Penelitian Kesehatan Suara Forikes 1: 105-114.

Christi AY, Ramzi S, Irawan FK (2013). Hubungan Pengetahuan Ibu tentang Stimulasi Dini dengan Perkembangan Motorik pada Anak Usia 6-24 bulan di Kecamatan Mayang Kabupaten Jember. Jurnal Pustaka Kesehatan 1(1): 2023.

Cohen SE, Beckwith L, Parmelee AH (2012). Reseptive language development in preterm children as related to caregiver child interaction. Pediatrics 20: 16-19.

Departemen Kesehatan RI (2009). Buku Kesehatan Ibu dan Anak. Cetakan I. Jakarta.

Dinkes Jateng (2015). Profil Kesehatan Provinsi Jawa Tengah Tahun 2015.

IDAI (2013). Mengenal keterlambatan perkembangan umum pada anak. http: // www.idai.or.id/artikel/seputarkesehatan-anak/mengenal-keterlambatan-per- 
kembangan-umum-pada-anak. Diakses pada tanggal 6 Juni 2016.

Kemenkes RI (2015). Sekretariat Jenderal Profil Kesehatan Indonesia Tahun 2014. Jakarta.

National Institute Of Child Health And $\mathrm{Hu}-$ man Development (NICHD) (2006). Study of early child care and youth development (SECCYD).

Pancsofar N, Vemon Feagans L (2006). Mother and father language input to young children: contributions to later language development. J App Dev Psy 27: 571-587.

Sharma S, Nagar S (2009). Influence of home environment on psychomotor development of infants in Kangra district of Himachal Pradesh. J Soc Sci 21: 225229.

Soetjiningsih (2013). Tumbuh Kembang Anak. Edisi 2. Jakarta: EGC.

Susanto A (2011). Perkembangan Anak Usia Dini, Pengantar dalam berbagai aspeknya. Jakarta: Kencana Prenada Media Group.

Wong DL, Chan RKW, Koh D, Tan HH, Lim FS, Emmanuel S, Bishop G (2008). Premarital Sexual Intercourse Among Adolescents in an Asian Country: multilevel Ecological Faktors Pediatrics. 